\title{
THE RELATION BETWEEN ACCOUNTING COMPARABILITY \\ AND FIRM PRODUCTIVITY
}

\begin{abstract}
Using a comprehensive sample of U.S. manufacturing firms from 1992 to 2015, I test for the association between accounting comparability and firm productivity. I posit that increased accounting comparability facilitates learning from peer firms ultimately increasing firm productivity. Results show that accounting comparability is positively related to firm productivity, and that one channel for this relation is improvement in inventory management. In cross-sectional analysis, I find that the relation between accounting comparability and firm productivity is stronger when 1) peer firms exhibit higher productivity and provide more informative filings; 2) subject firms exhibit higher product similarity with peer firms and face stiffer competition, and 3) subject firms operate in industries characterized by higher accounting quality.
\end{abstract}

JEL classifications: G12, G14, O32

Keywords: accounting comparability, firm productivity, inventory management 


\section{THE RELATION BETWEEN ACCOUNTING COMPARABILITY AND FIRM PRODUCTIVITY}

\section{Introduction}

One of the main drivers of profitability is productivity (Hasan et al., 2018) hence, studies examining the drivers of productivity are of public interest. Productivity is the efficiency by which inputs to the production process are converted into outputs. Even though researchers have made great strides in determining the drivers of productivity, the influence of the accounting system on firm productivity remains unclear.

In this study, I test for the relation between accounting comparability of a subject firm with its industry peers and subject firm productivity. Like prior literature ${ }^{1}$ I capture firm productivity using total factor productivity (TFP), that captures output not explained by production factor inputs. Accounting comparability is measured using the measure from De Franco et al. (2011) that captures similarity in the accounting policies used by firms as well as similarity in how such accounting policies are implemented by firms. De Franco et al. (2011) defines accounting comparability as the similarity with which firms map economic events to accounting numbers. I posit a positive association between accounting comparability and firm productivity, where firms with greater accounting comparability with their peers learn about the productivity enhancing activities of peer firms. This learning allows the subject firm to improve its productivity.

The approach adopted in this paper is different from that used in most prior literature. Specifically, most prior literature examines the influence of firm specific accounting choices on its own or its peer firm decision-making. For example, Biddle et al. (2009) find that subject firm

\footnotetext{
${ }^{1}$ Examples of such literature includes Schoar, (2002), Levinsohn and Petrin (2003), Yasar et al., (2008), Imrohoroglu and Tuzel (2014), Darrough et al., (2018), To et al., (2018) and Barrios et al., (2019).
} 
accounting quality is related to subject firm investment efficiency, while Badertscher et al. (2013), Beatty et al. (2013) and Shroff et al. (2014) show that subject firm accounting choices influence peer firm investment decisions and vice versa. In this study, like Chen et al. (2018) and Chircop et al. (2020), I study how a shared accounting characteristic influences subject firm decisionmaking. Hence, while in most prior literature accounting choices of one firm influence the accounting characteristic under study, accounting comparability is a function of the accounting choices of two firms where both firms need to make similar accounting choices.

This study also differs in its approach from Chen et al. (2018) and Chircop et al. (2020). The former study examines the role of accounting comparability in the M\&A process and investigates how accounting comparability of a target firm with its peer firms influence acquirer decision making. The study finds that higher target firm accounting comparability improves acquirer M\&A outcomes. In contrast, like Chircop et al. (2020), this study examines how a firm's own accounting comparability influences its own decision making. Chircop et al. (2020) examines the relation between accounting comparability and innovative efficiency and finds that accounting comparability improves innovative efficiency. The authors attribute this relation to the ability of a subject firm to learn from peer firm investment decisions in the presence of high accounting comparability. While both Chen et al. (2018) and Chircop et al. (2020) examine the influence of accounting comparability on investment decision making, I study the influence of accounting comparability on operating decision making as captured by TFP. ${ }^{2}$

Using a comprehensive sample of U.S. publicly traded manufacturing firms from 1992 to 2015, I find a positive association between accounting comparability and firm productivity. Specifically, an increase in accounting comparability from the median to the 75 th percentile of

\footnotetext{
${ }^{2}$ Operating decisions refer to determinations with respect to routine, ongoing activities of the organisation. Operating decisions are decisions other than investing or financing decisions.
} 
my sample is associated with an increase of 0.015 in firm TFP ceteris paribus. ${ }^{3}$ To identify the mechanism which drives the relation between accounting comparability and firm productivity I examine a management practice captured by TFP and which is particularly pertinent to manufacturing firms, lean inventory management (Bloom and Van Reenen 2007). This practice, which espouses techniques such as Just-In-Time (JIT) manufacturing, is often identified as a key management practice of successful U.S. manufacturing firms (Chen et al., 2005). I find that accounting comparability facilitates subject firm learning from peer firm JIT practices. This learning allows subject firms to improve their inventory management practices, ultimately improving their productivity. Further, I show that the association between accounting comparability and firm productivity is stronger when 1) peer firms exhibit high productivity and provide more informative filings; 2) subject firms' exhibit high product similarity with peer firms and face stiffer competition, and 3) subject firms operate in industries characterized by higher accounting quality.

This study contributes to prior literature along multiple dimensions. First, I contribute to the literature on accounting comparability by showing that accounting comparability is not only associated with an improved information environment for analysts (De Franco et al., 2011), management's external investment decisions (Chen et al., 2018) and innovative efficiency (Chircop et al, 2020), but is also associated with higher firm productivity. Hence, this study provides first evidence that accounting comparability is not only associated with better one-off investment decision making but is also associated with improved day-to-day operating decision making. Second, I contribute to the literature on the drivers of firm productivity. While prior literature has identified various drivers of firm productivity (Syverson, 2011) this is one of the first studies that documents how characteristics of the accounting system influence productivity.

\footnotetext{
${ }^{3}$ Mean (median) total factor productivity for my sample is $-0.019(-0.038)$.
} 
Specifically, this study complements Hann et al. (2020) which shows that productivity is more dispersed in industries with poor reporting quality. This study differs from Hann et al. along two dimensions. First, unlike financial reporting quality, accounting comparability is a function of the accounting choices of the subject and peer firms. Second, while Hann et al. examine productivity dispersion in industries, I examine the effect of an accounting characteristic on firms' own productivity.

\section{Literature Review}

\subsection{Firm productivity}

Productivity is often defined as the efficiency by which inputs in the production process are converted into outputs (Serpa and Krishnan, 2017). Total factor productivity (TFP), a common measure of firm productivity, is invariant to the intensity of observable input factors. Hence, higher-TFP producers generate more outputs relative to lower-TFP producers for the same amount of inputs. TFP represents Hicksian-factor neutral productivity differences between firms where higher-TFP firms have isoquants shifted up and to the right of lower-TFP firms (Bloom and Van Reenen 2007). Importantly changes in factor prices that drive factor intensity differences do not affect TFP, since such changes induce shifts along rather than in isoquants (Breunig and Wong, 2005; Barrios et al., 2019). Prior literature identifies several drivers of productivity. Two such drivers are resource misallocation and productivity spillovers.

Restuccia and Rogerson (2008) propose a growth model where misallocation of resources across firms that differ in productivity levels leads to lower aggregate productivity, as captured by TFP. Hsieh and Klenow (2009) quantify the effect of resource misallocation on aggregate productivity and find that this effect is economically significant. David et al. (2016) links the effect of resource misallocation across firms on aggregate productivity, to informational frictions at the firm level and Choi (2021) proposes a model where the use of accrual accounting within 
the firm improves managers' information about future productivity, hence enabling firms to make better capital and labor investment decisions. ${ }^{4}$ In a similar vein Hann et al. (2020) find that accounting quality attenuates external market participants (e.g. investors, customers or suppliers) information frictions about the distribution of productivity within an industry. Like Choi (2021) and Hann et al. (2020), I posit that characteristics of the accounting system influence productivity, however, unlike these studies I examine how accounting comparability improves subject firm productivity by facilitating subject firm learning about peer firm productivity enhancing management practices.

Productivity spillovers occur when the practices of one firm influence the productivity levels of other firms. Griffith et al. (2006) examine the geographic location of UK firms' R\&D operations and find that UK firms with R\&D activities in the US have faster overall productivity growth. They conclude that the US presence of such firms enables UK firms to tap the knowledge base of the US economy, which tends to be the technological leader in most industries. Bartelsman et al. (2008) compares productivity spillover effects between global and economy-specific industry leaders and finds that a plant's productivity converges faster to the industry domestic leader than the global industry leader. Crespi et al. (2008) and Keller and Yeaple (2009) use production microdata and survey data to examine information flows that lead to cross-border productivity convergence. They find that suppliers and competitors are main sources of information and that having a multinational presence facilitates cross-border information flows. Serpa and Krishnan (2017) examine productivity spillovers at the firm level and find evidence of significant customer-supplier productivity spillover effects. While these studies attribute productivity convergence to spillover effects, it is unclear how such productivity spillovers occur.

\footnotetext{
${ }^{4}$ In line with prior literature (e.g. Feng et al., 2009; Dichev et al., 2013; Goodman et al., 2014; Shroff, 2017), Choi (2021) finds that accruals enable firms to measure their performance more accurately, hence improving production decisions.
} 
This study aims to contribute to this literature by identifying accounting comparability as a channel through which productivity spillovers occur.

\subsection{Accounting comparability}

Accounting information is comparable when similar economic events lead to accounting numbers which are similar, while different economic events lead to different accounting numbers. The Financial Accounting Standards Board (FASB, 2010) emphasizes that rational decisionmaking requires accounting numbers that are comparable so that users can evaluate similarities and differences in investment opportunities.

De Franco et al. (2011) defines accounting comparability as the degree to which similar economic events are mapped into accounting numbers that are similar. Specifically, De Franco et al. suggests that similarity between the parameter estimates for firm specific regressions of earnings on returns, for the subject firm and peer firms within the same industry, adequately capture the notion of accounting comparability..$^{5}$ By using earnings to capture how economic events are captured in accounting numbers, the De Franco et al. measure effectively captures not only similarity in the accounting policies used by the subject and peer firms, but also similarities in how such accounting policies are implemented. This is a major advantage over other measures of accounting comparability which only capture similarities in the accounting policies used by firms. Implementation considerations are particularly pertinent in the context of firm productivity since peer firm unit inputs and outputs are mostly unobservable and external stakeholders have to rely on accounting numbers to evaluate the productivity of peer firms (Hann et al., 2020).

Two studies, which make use of the De Franco et al. measure of accounting comparability and which are closely related to this study are Chen et al. (2018) and Chircop et al. (2020). Chen et al. (2018) finds that acquirers make better acquisition decisions when target firms exhibit

\footnotetext{
${ }^{5}$ Details on the computation of accounting comparability are discussed in section 4 .
} 
greater accounting comparability with peer firms. Conversely, Chircop et al. (2020) finds that accounting comparability of a subject firm with its peer firms improves subject firm investment efficiency as evidenced by improved innovative efficiency.

While Chen et al. (2018) and Chircop et al. (2020) examine the relation between accounting comparability and investment decisions, this study examines the relation between accounting comparability and operating decisions. Operating decisions captured by TFP relate to management practices such as inventory management, performance tracking and promotion decisions (Bloom and Van Reenen, 2007). These operating decisions tend to be less easily observable than the large infrequent investment decisions. Given this, it is unclear whether accounting comparability facilitates knowledge transfer with respect to more mundane but important firm decisions.

\section{Hypothesis development}

\subsection{Accounting comparability and firm productivity}

For productivity spillovers to occur the subject firm must be able to observe, identify and understand the productivity enhancing activities of a peer firm. If as suggested by De Franco et al. (2011), accounting comparability reduces information acquisition costs and increases the amount and quality of information available, then accounting comparability should facilitate learning from peer firms. Note that accounting comparability does not only facilitate learning from peer firm financial statements, which tend to contain aggregated data, but also from the information disclosed by the firm throughout the year (Chircop et al., 2020). ${ }^{6}$

Prior literature finds that accounting comparability improves corporate investment decision making. Chen et al. (2018) find that accounting comparability improves acquirer M\&A decisions while Chircop et al. (2020) conclude that accounting comparability improves R\&D investments.

\footnotetext{
${ }^{6}$ For example, having a similar accounting system to a peer firm allows the subject firm to better understand the notes to the financial statements, earnings announcements and market updates.
} 
I maintain that if subject firms' accounting choices are similar to those of peer firms, the subject firm will be better able to identify and understand productivity enhancing management practices of peer firms ultimately improving its own productivity. I formalize this prediction in the following hypothesis:

H1: Subject firms with greater accounting comparability with industry peer firms exhibit greater firm productivity.

One channel through which accounting comparability with peer firms improves subject firm productivity is by improving subject firm understanding of peer firm inventory management practices. Japanese lean manufacturing techniques such as Just-In-Time (JIT) inventory systems were seen as revolutionary and subsequently adopted by U.S. companies (Bloom and Van Reenen, 2007). Effective inventory management is important as while productive inputs need to be available when needed, holding inventory takes space, ties capital and can permit slack ultimately reducing firm productivity (Chen et al., 2005). Learning about peer firm inventory management practices from the information on inventories (e.g. amounts of raw materials, work-in-progress and finished goods) available in peer firm financial statements allows subject firms to improve their own inventory management practices. ${ }^{7}$ I maintain that greater accounting comparability with peer firms, especially peer firms adopting JIT practices, facilitates subject firm learning about inventory management practices that improve subject firm productivity. I formalize this prediction in the following hypothesis:

H2: Subject firms with greater accounting comparability with industry peer firms, especially peer firms adopting JIT practices, improve their inventory management practices.

\subsection{Cross-sectional predictions-peer firm characteristics}

Hypothesis 1 assumes that the relation between subject firm accounting comparability with peer firms and subject firm productivity is independent of peer firm productivity. However,

\footnotetext{
${ }^{7}$ Notwithstanding that financial statement line items tend to be highly aggregated, peer firm financial information about the relation between firm performance and inventory provides subject firms with insights about how strictly JIT practices are being implemented.
} 
this may not be the case. Greater accounting comparability with peer firms exhibiting high productivity allows the subject firm to identify the productivity enhancing activities that it needs to replicate to improve its own firm productivity. Conversely, there is less scope for learning from peer firms that exhibit low productivity. Learning from these firms is restricted to identifying activities which impede firm productivity, and which should not be replicated by the subject firm. Thus, while learning from both high and low productivity peer firms improves subject firm productivity, there is greater scope for improving subject firm productivity by learning from high productivity peer firms.

Further, the more information peer firms provide in their public filings, the greater the ability of accounting comparability to facilitate subject firm learning. By construction the provision of more information increases the size and length of public filings. ${ }^{8}$ Put differently, there is greater scope for subject firm learning from peer firm financial statements, if peer firms submit larger and longer public filings. I formalize these predictions in the following hypotheses:

H3a: The association between subject firm accounting comparability and subject firm productivity is stronger if peer firms exhibit high productivity.

H3b: The association between subject firm accounting comparability and subject firm productivity is stronger if peer firms submit larger and longer public filings.

\subsection{Cross-sectional predictions—-subject firm characteristics}

Firms with high product similarity with industry peers are more likely to benefit from accounting comparability with peer firms, as operating activities will be similar. Further, product similarity facilitates product substitution, hence increasing firm competition (Syverson 2004a; Bloom et al., 2011; Bloom et al., 2013). Firms facing stiffer competition have a stronger incentive to increase their efficiency since failure to do so will cast doubt about their future. In this ambit,

\footnotetext{
${ }^{8}$ Loughran and McDonald (2014) find that larger and longer 10-K filings cause ambiguity in investor and analyst assessment of the company as captured by stock volatility and analyst forecast errors, however this is less likely the case when filings are being examined by peer firms operating in narrowly defined industries.
} 
Syverson (2004a) and Schmitz (2005) provide evidence of increased productivity resulting from greater competition. Using the ready-mix industry Syverson (2004b) demonstrates that increased product substitutability truncates productivity dispersion from below, while using the iron ore industry Schmitz (2005) shows how the sudden import of cheap iron ore from Brazil led U.S. and Canadian ore industries to significantly increase their productivity. Given these results, I expect firms with high product similarity and firms facing stiffer competition to have greater incentives to take advantage of accounting comparability to improve their productivity. I formalize these predictions in the following hypotheses:

H4a: The association between subject firm accounting comparability and subject firm productivity is stronger when subject firms have high product similarity with peer firms.

H4b: The association between subject firm accounting comparability and subject firm productivity is stronger when subject firms face stiffer competition.

\subsection{Cross-sectional predictions-industry characteristics}

Prior literature finds that financial statements with higher accounting quality are more informative to financial statement users. Biddle and Hilary (2006) and Biddle et al. (2009) conclude that accounting quality improves decision making by reducing the information asymmetry between the firm's management and outside providers of capital. I posit that the relation between accounting comparability and productivity is stronger if the firm is operating in an industry exhibiting high accounting quality since high accounting quality facilitates subject firm learning from peer firms. I formalize this prediction in the following hypothesis:

H5: The association between subject firm accounting comparability and subject firm productivity is stronger when subject firms operate in industries exhibiting higher accounting quality.

\section{Research design, data sources and variable measurement}

\subsection{Data sources and sample selection}

The sample for this study consists of firm-year observations at the intersection of COMPUSTAT, CRSP, Thomson Reuters Institutional (13f) Holdings data and the Quarterly 
Census of Employment and Wages (QCEW) available through the Bureau of Labor Statistics. ${ }^{9}$ Moreover, in testing hypothesis 3b I use data from the WRDS SEC Analytics Suite and in testing hypotheses $4 \mathrm{a}$ and $4 \mathrm{~b}$, I use data on firm product similarity and competition sourced from the Hoberg -Phillips Data Library. ${ }^{10}$

The sample period is 1992 to 2015 and like prior literature (e.g Hann et al., 2020) I focus on the manufacturing industry. Manufacturing firms tend to have clearly identifiable production processes which allows for the calculation of firm productivity with less measurement errors. Thus, the initial sample consists of all COMPUSTAT firms where the first two digits of their 4digit NAICS code are 31, 32 or 33. Like De Franco et al. (2011), I drop holding companies, group companies, limited partnerships and American Depository Receipts (ADRs). I also drop firms with missing (or non-positive) sales, gross property, plant and equipment, and number of employees. Finally, I drop observations for which I am not able to compute the vector of control variables used in the empirical analysis. The final sample consists of 16,340 observations for 1,900 unique manufacturing firms.

\subsection{Measuring firm productivity}

Like prior studies I use Total Factor Productivity (TFP) as my measure of firm productivity. ${ }^{11,12}$ TFP is based on the value-added approach, which addresses inconsistencies resulting from variation in the inputs and outputs across industries. Like Serpa and Krishnan (2017) I compute value added as the difference between sales and material expense. Material expense is defined as total expenses minus labor expenses, where total expenses equal sales minus operating income before depreciation and amortization. Labor expenses are computed as the QCEW 4-digit NAICS average annual pay multiplied by the total number of employees.

\footnotetext{
${ }^{9}$ These data are publicly available at: https://www.bls.gov/cew/home.htm.

${ }^{10}$ The Hoberg-Phillips Data Library is publicly available at: http://hobergphillips.usc.edu/.

${ }^{11}$ TFP has been used by Imrohoroglu and Tuzel (2014), Serpa and Krishnan, (2017) and Darrough et al., (2018) to capture productivity.

${ }^{12}$ I obtain similar inferences to those documented in this study when I use single factor measures (e.g. labor productivity or capital productivity) of productivity.
} 
To estimate TFP I follow Serpa and Krishnan (2017) and start from a log-linear CobbDouglas production function ${ }^{13}$ :

$y_{i t}=\alpha+\beta_{l} l_{i t}+\beta_{k} k_{i t}+T F P_{i t}+\varepsilon_{i t}$

where $y$ is the log of value added, the measure of output, for firm $i$ in year $t$, and $k$ and $l$ represent the firm capital and labor inputs respectively. Capital is the log of gross property, plant and equipment for the firm while labor is the log of the number of employees employed by the firm. The error term, $\varepsilon$, represents a firm specific random shock and TFP represents output not explained by firm inputs, capital and labor. ${ }^{14}$ If I let $\hat{\alpha}, \hat{\beta}_{l}$ and $\hat{\beta}_{k}$ represent the input elasticities then I can obtain log-TFP using Eq.2 below:

$\widehat{T F P}_{i t}=y_{i t}-\hat{\beta}_{l} l_{i t}-\hat{\beta}_{k} k_{i t}-\hat{\alpha}$

While this value-added approach is common when estimating firm productivity, estimating Eq. 1 using OLS raises two key issues: simultaneity and selection bias. ${ }^{15}$ To address these issues and deal with the "within firm serial correlation in productivity that plagues many production function estimates" (Imrohoroglu and Tuzel 2014, 2075) I use the method proposed by Olley and Pakes (1996) where capital investment (i.e. Capex) is used to proxy for capital stock. ${ }^{16}$ This method assumes a monotonic relationship between Capex and true productivity

\footnotetext{
${ }^{13}$ An alternative approach to using the parametric Cobb-Douglas approach to measuring firm productivity, is to use nonparametric methods such as data envelopment analysis (DEA). A Cobb-Douglas approach assumes only one output resulting from multiple inputs where the error term is defined in a structurally composed manner (Aigner et al., 1977). Specifically, a Cobb-Douglas approach recognises that shocks outside the control of producers influence production output. Hence, in such an approach the impact of random shocks (e.g. labor and capital performance) on productivity can be distinguished from impact of technical efficiency variation (Meeusen and van den Broeck, 1977). Conversely a DEA approach can estimate a production function with multiple inputs and outputs (Banker and Morey, 1986) in that for each firm under analysis, the best set of weights is assigned to give it the highest ratio of outputs over inputs, subject to no firm having a ratio larger than one (Charnes et al., 1978).

${ }^{14}$ Further, in Eqs.1 and $2 \mathrm{I}$ include firm and year fixed effects to abstract the effect of time invariant firm characteristics and time effects from the computed parameter estimates. I omit these fixed effects from the specification of Eqs. 1 and 2 above to facilitate exposition.

${ }^{15}$ The simultaneity bias arises because firm outputs and inputs are simultaneously determined. In other words, outputs and inputs to the production process are jointly determinable. Given that labor and capital are simultaneously determined with TFP, the covariates are correlated with the error terms. The selection bias arises because firms with large capital stock are less likely to exit the market. As capital stock is one of the explanatory variables in Eq.1, by construction TFP is subject to selection bias.

${ }^{16}$ This method has been extensively used in prior literature. Refer to Ackerberg et al. (2007) for a survey of empirical studies that use the Olley and Pakes (1996) approach.
} 
shocks, and hence require Capex to be positive as productivity shocks are rarely negative (To et al., 2018). In addition, the semiparametric approach suggested by Olley and Pakes (1996) defines labor as a variable input which is adjusted in response to current productivity and defines capital as a fixed input where capital used in period $t$ is defined in period $t-1$. Finally, to correct for the functional dependence problems inherent in the Olley and Pakes (1996) estimation procedure, I estimate TFP with the Ackerberg et al. (2015) correction. ${ }^{17,18,19,20}$

\subsection{Measure of accounting comparability}

As my measure of accounting comparability, I use the measure proposed by De Franco et al. (2011), where accounting comparability is defined as the similarity in which similar economic events are mapped into accounting numbers. Like De Franco et al. I capture accounting comparability by examining the relation between market returns and accounting earnings. Market returns capture economic events while accounting earnings capture how economic events are mapped to the accounting system.

To calculate accounting comparability of a firm, $i$, I first calculate the relation between earnings and returns for the 16 quarters $^{21}$ prior to year $t$. Specifically, I use the following OLS regression:

Earnings $_{i t}=\alpha_{i}+\beta_{i}$ Return $_{i t}+\varepsilon_{i t}$

where Earnings is quarterly net income before extraordinary items scaled by the beginning of period market value of equity while Return is the stock market return during the quarter calculated

\footnotetext{
${ }^{17}$ Refer to Ackerberg et al. (2015) for a discussion of the functional dependence problems inherent in the estimation of production functions.

18 Prior literature has proposed various other methods (e.g. Wooldridge, 2009; Levinshon and Petrin, 2013) to compute firm productivity. In robustness tests presented in the Internet Supplement, I test the sensitivity of my results to different measures of firm productivity. Inferences from these tests are similar to those presented in this study.

${ }^{19}$ Stata command 'prodest' is used to generate TFP using the Olley and Pakes (1996) approach with the Ackerberg et al. (2015) correction.

${ }^{20}$ There are other limitations to the calculation of TFP. Specifically, in calculating TFP, I lack information about the quality of the inputs and the utilization of such inputs by the firm. Notwithstanding these issues, Syverson (2011, 332) finds that productivity estimates are "robust to measurement peculiarities ... [since] variation in establishment or firm - level microdata is typically so large as to swamp any small measurement induced differences in productivity metrics."

${ }^{21}$ For each observation, I require data for at least 14 of the 16 quarters.
} 
as the exponential of the sum of monthly returns during the quarter minus one. The parameter estimates in Eq.3, the intercept $\left(\hat{\alpha}_{i}\right)$ and slope coefficient $\left(\hat{\beta}_{i}\right)$, give the firm-specific mapping of economic events to the accounting of firm $i$.

Similarly, I use Eq. 3 to capture how the accounting system of a peer firm $j$ maps economic events to accounting, where $\hat{\alpha}_{j}$ and $\hat{\beta}_{j}$ capture peer firm $j$ accounting system. When the parameter estimates are applied to subject firm $i$ returns as in Eqs.4 and 5 I can calculate the expected earnings arising from firm $i$ and firm $j$ accounting systems when facing the same economic events. The superscript on Earnings in Eqs.4 and 5 capture the firm whose returns are used in the equations, while the subscript on Earnings captures the firm whose parameter estimates are used in the equations.

$$
\begin{aligned}
& E\left(\text { Earnings }_{i, t}^{i}\right)=\hat{\alpha}_{i}+\hat{\beta}_{i} \text { Return }_{i t} \\
& E\left(\text { Earnings }_{j, t}^{i}\right)=\hat{\alpha}_{j}+\hat{\beta}_{j} \operatorname{Return}_{i t}
\end{aligned}
$$

Accounting comparability between subject firm $i$ and peer firm $j$ is the cumulative absolute difference between the expected earnings computed in Eqs.4 and 5. This computation is formalized in Eq.6.

$$
\operatorname{CompAcct}_{i j t}=\frac{1}{\tau} \sum_{t}^{\tau} \mid E\left(\text { Earnings }_{i, t}^{i}\right)-E\left(\text { Earnings }_{j, t}^{i}\right) \mid
$$

where $\tau$ is the number of quarters in the estimation period. In Eq.6, the more comparable the accounting system of subject firm $i$ to the accounting system of peer firm $j$, the smaller CompAcct. To facilitate interpretation, I multiply CompAcct by minus one so that the less negative CompAcct, the higher the accounting comparability. I calculate CompAcct for each subject-peer firm combination, where the subject firm is a manufacturing firm in COMPUSTAT while peer firms are all other firms in the same 4-digit NAICS code as the subject firm. ${ }^{22}$ I use the

\footnotetext{
${ }^{22}$ This ensures that the same industry definition is used in the calculation of both accounting comparability and firm productivity.
} 
average $^{23}$ of CompAcct for each subject-peer firm combination, which I call COMP, as my measure of accounting comparability.

\subsection{Empirical model examining the relation between accounting comparability and firm productivity}

To test hypothesis 1, I estimate the following OLS regression model:

$$
\begin{aligned}
& \text {TFP }_{i t+1}=\beta_{0}+\beta_{1} \text { COMP }_{i t}+\beta_{2} \text { SIZE }_{i t}+\beta_{3} A G E_{i t}+\beta_{4} \text { MTB }_{i t}+\beta_{5} L_{E V_{i t}}+\beta_{6} \text { CAPINT }_{i t}+ \\
& \beta_{7} \text { TOBINQ }_{i t}+\beta_{8} \text { CURRENTRATIO }_{i t}+\beta_{9} I O_{i t}+\beta_{10} S E G_{i t}+\beta_{11} A Q_{i t}+\beta_{12} \text { SYNC }_{i t}+ \\
& \beta_{13} \text { CORR }_{i t}+\beta_{14} \text { STDOCF }_{i t}+\text { Industry F.E. }+ \text { YearF.E. }+\varepsilon_{i t}
\end{aligned}
$$

where $T F P$ is total factor productivity, and $C O M P$, accounting comparability, is my explanatory variable of interest. As discussed in section 4.2, TFP captures firm output that cannot be explained by firm inputs, while as discussed in section 4.3, COMP captures the average difference in the mapping of returns into accounting earnings between the subject firm and peer firms over the previous 16-quarters. As shown in Figure 1, TFP is measured at $t+1$ while all independent variables are measured at $t$ to reflect the natural time delay between learning from peer firms and the changes to management practices captured by TFP. Put differently, Eq. 7 assumes that subject firm productivity at time $t+1$ is a function of learning from peer firms over time period $t-3$ to $t .^{24}$

$<<$ Insert Figure 1 here $>>$

SIZE, AGE, MTB, LEV, CAPINT, TOBINQ, CURRENTRATIO, IO, SEG, AQ, SYNC, CORR, STDOCF, Industry F.E and Year F.E. refer to the vector of control variables used in the model. SIZE, calculated as the logarithmic transformation of total assets, is used to control for financial constraints (Livdan et al., 2009) and for the positive association between firm size and productivity observed in Imrohoroglu and Tuzel (2014). AGE, computed as the difference between year $t$ and the first year in which the firm appears in CRSP, controls for operating

\footnotetext{
${ }^{23}$ I obtain qualitatively similar results, if I compute COMP as the median instead of the average CompAcct for each subject firm.

${ }^{24}$ The choice of 16-quarters (period $t$-3 to $t$ ) to calculate accounting comparability is based on De Franco et al. (2011). Inferences obtained on the relation between accounting comparability and firm productivity are conditional on the extent to which period $t-3$ to $t$ accurately identifies the period over which subject firm learning from peer firms occurs.
} 
experience since Levitt et al. (2011) and Kellogg (2009) find that productivity increases with experience. $M T B$, market-to-book ratio, calculated as the market capitalization at the end of the financial year scaled by net assets, controls for the firm growth prospects. I control for leverage ( $L E V)$, computed as long-term debt scaled by total shareholders' equity, because Imrohoroglu and Tuzel (2014) find that low productivity firms have high leverage. CAPINT, capital intensity, computed as the log of total assets scaled by the number of employees, controls for the mix of inputs to the production process. I control for the firm investment opportunity set using $T O B I N Q$, calculated as the sum of the firm market value and total debt scaled by total assets. CURRENTRATIO, current ratio, calculated as current assets scaled by current liabilities, controls for the potential link between the type of firm operations and productivity. I control for organizational structure using $I O$, institutional ownership and $S E G$, the log of the number of firm segments because prior literature has found evidence that organizational structure influences firm productivity (Maksimovic and Phililips, 2002; Schoar, 2002; Hortaḉsu and Syverson, 2007; Atalay et al. 2012).

I control for accounting quality, $A Q$, because Biddle and Hilary (2006) and Biddle et al. (2009) find that accounting quality improves investment efficiency. Like McNichols (2002) I measure accounting quality as the standard deviation of the residuals from estimating an OLS regression where the dependent variable is change in working capital and the independent variables are the explanatory variables in the Jones (1991) and the Dechow and Dichev (2002) models, over the same 16 quarters used to calculate accounting comparability. ${ }^{25}$ To facilitate interpretation, I multiply the standard deviation of residuals by minus one, rank the values into deciles and divide the resulting values by nine. In this way, $A Q$ ranges between 0 and 1 , and larger values of $A Q$ indicate higher accounting quality.

\footnotetext{
${ }^{25}$ I follow McNichols (2002) and estimate accounting quality using the following model: $\Delta W C_{t}=b_{0}+b_{1} C F O_{t-1}+$ $b_{2} \mathrm{CFO}_{t}+b_{3} \mathrm{CFO}_{t+1}+b_{4} \triangle$ Sales $_{t}+b_{5} P P E_{t}+\varepsilon_{t}$ where $\triangle W C$ is changes in working capital, CFO is cash from operations, $\triangle$ Sales is changes in sales and $P P E$ is property, plant and equipment. All variables are deflated by average total assets.
} 
To ensure that my measure of accounting comparability is capturing similarity in accounting systems and not similarity in the underlying economics or operating environment, I include $S Y N C$ and CORR in the model. Synchronicity, SYNC, captures the degree to which firm returns are explained by market returns and is measured as the adjusted r-squared from a market model OLS regression estimated over the same 16 quarters used to compute COMP. Correlation, $C O R R$, is the average correlation of subject firm market returns with peer firm market returns over the same 16 quarters used to compute COMP, where peer firms are firms in the same 4-digit NAICS industry as the subject firm. Further, to ensure that my measure of accounting comparability is not capturing firm idiosyncratic risk, I use the coefficient of variation of operating cash flows over the 16 quarters used to compute COMP as one of my control variables. To facilitate interpretation, the coefficient of variation is ranked into deciles and divided by nine, so that $O C F V O L$ ranges between 0 and 1.

I include industry fixed effects because prior literature shows that industry-specific characteristics such as the size of sunk costs (Collard-Wexler, 2013), competition (Syverson, 2004b; Schmitz 2005; Bloom et al., 2011); product market rivalry (Bloom et al., 2013) and regulation (Pavcnik, 2002; Bridgman et al., 2009; Knittel, 2002; Fabrizio et al., 2007; Arnold et al., 2008; Greenston et al, 2012) influence productivity. Furthermore, to control for changes in productivity due to developments in information technology over my sample period I include year fixed effects. ${ }^{26}$ I winsorize all continuous variables at the $1 \%$ level and cluster standard errors by firm and year in all regressions.

\subsection{Summary statistics}

Panel A of Table 1 shows summary statistics ${ }^{27}$ for the variables used in Eq.7. Being the residual of a Cobb-Douglas function ${ }^{28}$, observations for TFP cluster around 0 . The mean (median)

\footnotetext{
${ }^{26}$ In robustness tests presented in the Internet Supplement, I run Eq.7 including industry fixed effects interacted with year fixed effects. Results for this test are similar to the results presented in this study.

${ }^{27}$ Distributional statistics for the sample are presented in the Internet Supplement.

${ }^{28}$ See S.4.2 for details of how TFP is calculated.
} 
TFP is $-0.019(-0.038)$. The independent variable of interest, COMP has a mean (median) of $3.037(-2.630)$ and a standard deviation of 1.882. By construction all values for COMP have a negative sign, with smaller negative values indicating greater accounting comparability. The Correlation matrix for the variables of interest is presented in Panel B of Table 1. Correlation coefficients in bold denote statistical significance at the $10 \%$ level. In line with hypothesis 1 I find a positive and significant correlation between firm productivity, TFP and accounting comparability, COMP. Further, in line with prior literature I find that SIZE, MTB, CAPINT, CURRENTRATIO, IO and STDOCF are positively correlated with TFP.

$<<$ Insert Table 1 here >>

\section{Empirical results}

\subsection{Testing for the association between accounting comparability and firm productivity}

Table 2 presents the results from estimating Eq.7. Supporting hypothesis 1, I find a positive and significant relation between accounting comparability and firm productivity. Specifically, the coefficient (t-stat.) on COMP is 0.020 (6.19) and significant at the $1 \%$ level. This result suggests that firms with higher accounting comparability make better operational decisions leading to greater firm productivity. An increase in accounting comparability from the median to the 75 th percentile of the sample increases firm TFP by 0.015 ceteris paribus. $^{29}$

Results for control variables are generally in line with the univariate results in the Pearson correlation matrix presented in Table B of Table 1. Specifically, I find a positive and significant association between CAPINT, TOBINQ, IO, STDOCF and TFP. Conversely, MTB, CURRENTRATIO, SEG, AQ and CORR are negatively and significantly associated with TFP.

\footnotetext{
${ }^{29}$ An increase in COMP from the median to the $75^{\text {th }}$ percentile corresponds to an increase of $(-1.871-(-2.630)) 0.759$. Multiplying this increase by the coefficient on COMP (Table 2) of 0.020 gives an increase in TFP of 0.015 . Mean (Median) TFP for my sample is $-0.019(-0.038)$.
} 
$<<$ Insert Table 2 here $>>$

\subsection{Accounting comparability, inventory management practices and firm productivity}

Chen et al. (2005) suggest that low levels of raw material inventories indicate efficient dealings with suppliers; low levels of work-in-process inventory indicate efficient internal operations while levels of finished goods inventories are related to dealings with customers. Given that dealings with suppliers and customers are not fully within the control of the firm, I focus my analysis on the levels of work-in-process inventories. Specifically, if accounting comparability facilitate learning about productivity enhancing inventory management practices, then I should observe a negative relation between accounting comparability and work-in-process inventory held by the subject firm.

Following Chen et al. (2005) I use Eq.8, to compute the work-in-process inventory (WIP) to total assets $(A T)$ ratio, WIPAT, to capture the fraction of the firms' assets tied up in work-inprocess.

$W I P A T_{i t}=\frac{W I P_{i t}}{A T_{i t}}$

Asset ratios such as WIPAT are useful in making timeseries comparisons since by construction the ratio normalizes for firm size. Notwithstanding this, different industries have different inventory needs and any cross-sectional analysis needs to control for such differences. Hence to undertake my analysis, besides including industry fixed effects, I use the normalized deviation from the industry norm to capture whether the firm has lean or bloated inventory. Like Chen et al. I compute normalized deviation as:

$A B_{-} W I P_{i t}=\frac{\left(W I P A T_{i t}-I N D_{-} W I P A T_{i t}\right)}{S T D I N D_{-} W I P A T_{i t}}$

where IND_WIPAT and STDIND_WIPAT are the average and standard deviation of WIPAT for firms in the same 4-digit NAICS code as the subject firm. AB_WIP captures abnormal work-in- 
process inventory where a positive (negative) $A B \_W I P$ suggests that firm $i$ in period $t$ carries more (less) work-in-process inventory than industry peers. If accounting comparability enables subject firms to learn from the inventory management practices of peer firms, then subject firms with greater accounting comparability should have lower $A B_{-} W I P$. To test this conjecture, I substitute $T F P$ with $A B_{-} W I P$ in Eq. 7 . Like my main analysis, I measure $A B_{-} W I P$ at $t+1$ to allow for the time delay between learning from peer firms and the subject firm improving its inventory management practices.

Specification 1 of Panel A, Table 3 shows the results for this test. I find a negative and significant (coeff: -0.031 ; t-stat: -3.10 ) association between $C O M P$ and $A B \_W I P$ suggesting that firms with greater accounting comparability with peer firms have leaner inventory management practices. While it is possible that accounting comparability facilitates learning about inventory management practices from all peer firms, accounting comparability is likely more beneficial when it enables learning from peer firms exhibiting lean inventory management practices. These peer firms employ inventory management practices that allow them to carry lower work-inprocess inventory than industry peers. To test this conjecture, I create an indicator variable LOW_PEERWIP which takes the value of one if at least one of the four peer firms with the highest accounting comparability with the subject firm has a negative $A B_{-} W I P .{ }^{30}$ I run the adjusted Eq.7 including LOW_PEERWIP and an interaction term between $L O W \_P E E R W I P$ and COMP.

Specification 2 of Panel A, Table 3 shows the results for this test. In line with expectations the coefficient on the interaction term between $L O W \_P E E R W I P$ and COMP is negative and significant suggesting that subject firms reduce their work-in-process inventories more when they have high accounting comparability with peer firms exhibiting lean inventory management

\footnotetext{
${ }^{30}$ The choice of four firms with the highest accounting comparability to the subject firm is motivated by De Franco et al. (2011) who compute accounting comparability based on the four firms with greater accounting comparability to the subject firm.
} 
practices. Interestingly, the coefficient on COMP though positive is insignificant suggesting that there is limited learning with respect to effective inventory management practices from peer firms which exhibit bloated work-in-process inventories.

The above analysis shows that accounting comparability is related to lean inventory management however lean inventory management is a channel through which accounting comparability influence firm productivity only if it is related to greater firm productivity. To test, whether in line with Bloom and Van Reenen (2007), effective work-in-process inventory management is related to firm productivity, I include $A B_{-} W I P$ in Eq. 7. Like TFP, I measure $A B \_W I P$ at $t+1$ since any improvement in work-in-process inventory management should be immediately captured by $T F P$.

Panel B of Table 3 shows the results for this analysis. I find a negative and significant coefficient (coeff: -0.013; t-stat: -1.82) on $A B \_W I P$ suggesting that a decrease in work-in-process inventory is related to an increase in firm productivity. Further, like the results in Table 2, I find a positive and significant coefficient on COMP (coeff: 0.020; t-stat: 5.70) suggesting that workin-process inventory management is one of multiple channels through which accounting comparability influence firm productivity.

\section{$<<$ Insert Table 3 here >>}

\subsection{Accounting comparability, firm productivity and peer firm characteristics}

Hypothesis 3 a posits that accounting comparability with high productivity peer firms provides greater scope for learning, hence improving subject firm productivity more than accounting comparability with low productivity peer firms. To test hypothesis 3a, I create an indicator variable HIGH_PEERTFP which takes the value of one if at least one out of the four peer firms with the highest accounting comparability with the subject firm has a TFP above the sample mean for the year, and zero otherwise. I also include an interaction term between 
HIGH_PEERTFP and COMP in Eq. 7, to capture incremental improvement in subject firm TFP when the subject firm has high accounting comparability with peer firms exhibiting high productivity.

Panel A of Table 4 shows the results for this analysis. In line with hypothesis $3 a$, I find a positive and significant coefficient on the interaction between HIGH_PEERTFP and COMP (coeff: 0.013 ; t-stat: 1.82 ) suggesting incremental improvement in subject firm productivity in the presence of accounting comparability with peer firms exhibiting high productivity. Comparing the size of the coefficient on the interaction term to the size of the coefficient on COMP (coeff: 0.009; t-stat: 2.81 ) suggests a $34 \%$ incremental improvement in subject firm productivity in the presence of accounting comparability with peer firms exhibiting high productivity.

Hypothesis $3 \mathrm{~b}$ posits that the association between accounting comparability and subject firm productivity is stronger if peer firms submit larger and longer public filings. I capture the size of public filings using two distinct measures: FILESIZE, the mean 10-Q and 10-K file size for the same 16-quarters used to calculate COMP, and WORDCOUNT, the mean 10-Q and 10-K word count for the same 16-quarters used to calculate COMP. While the latter measure captures the length of text in firm public filings, the former measure captures the filing structure, graphics and other content in addition to the text found in public filings. Using FILESIZE (WORDCOUNT), I create an indicator variable $H I G H \_P E E R F I L E S I Z E$ (HIGH_PEERWORDCOUNT) which takes the value of one if at least one of the four peer firms with the highest accounting comparability with the subject firm has FILESIZE (WORDCOUNT) above the sample mean for the year. I test hypothesis $3 \mathrm{~b}$ by including HIGH_PEERFILESIZE (HIGH_PEERWORDCOUNT) and an interaction between HIGH_PEERFILESIZE (HIGH_PEERWORDCOUNT) and COMP in Eq. 7.

Panel B of Table 4 shows the results for this test. In both specifications I find a positive and significant association between the interaction term and TFP suggesting that the relation between accounting comparability and subject firm productivity is stronger when peer firms 
prepare more informative filings. Specifically, the coefficient on the interaction between HIGH_PEERFILESIZE (HIGH_PEERWORDCOUNT) and COMP is 0.010 (0.021) and significant at the $10 \%(1 \%)$ level.

$<<$ Insert Table 4 here $>>$

\subsection{Accounting comparability, firm productivity and subject firm characteristics}

To test hypotheses $4 \mathrm{a}$ and $4 \mathrm{~b}$ I use product similarity and Herfindahl-Hirschman Index (HHI) data from Hoberg and Phillips (2016). ${ }^{31}$ To test hypothesis 4a, I introduce two new variables in Eq.7. HIGH_SIM is an indicator variable that takes the value of one if product similarity is above the sample mean for the 4-digit NAICS code-year and zero otherwise, while COMP*HIGH_SIM is an interaction between COMP and HIGH_SIM. The interaction term captures the incremental effect of product similarity on the relation between accounting comparability and firm productivity.

Panel A of Table 5 shows the results for the specification testing hypothesis $4 \mathrm{a}$. In support of hypothesis $4 \mathrm{a}$, I find that the coefficient on the interaction term is positive and significant (coeff; 0.028 ; t-stat: 2.13 ) at the $5 \%$ level. This result suggests that subject firm product similarity with peer firms strengthens the relation between accounting comparability and firm productivity. Noteworthy is the positive and significant coefficient on the main effect COMP, suggesting that the relation between accounting comparability and productivity is irrespective of product similarity.

To test hypothesis 4b, I include HIGH_COMPETITION, an indicator variable that takes the value of one if subject firm HHI is below the sample mean for the 4-digit NAICS code-year and zero otherwise, and COMP*HIGH_COMPETITION, an interaction term between accounting

\footnotetext{
${ }^{31}$ These data have the advantage that they are based on the TNIC industry classification system which is firm specific, hence the measures of product similarity and industry concentration are specific to the subject firm. Firm-level product similarity data are based on a textual analysis of the product descriptions found in the 10-K business description sections. The product description found in $10-\mathrm{K}$ filings is legally required by Regulation $\mathrm{S}-\mathrm{K}$ and describes the significant products offered by the firm. The authors use the cosine similarity method to calculate the pairwise similarity in product descriptions.
} 
comparability and HIGH_COMPETITION, in my baseline specification. The interaction term captures the incremental effect of high competition on the relation between accounting comparability and firm productivity. Panel B of Table 5 shows the results for this test. In support of hypothesis $4 \mathrm{~b}$, I find a positive and significant coefficient on COMP*HIGH_COMPETITION suggesting that high competition strengthens the relation between accounting comparability and firm productivity.

$<<$ Insert Table 5 around here $>>$

\subsection{Accounting comparability, firm productivity and industry characteristics}

To test hypothesis 5, I transform $A Q$ into an indicator variable, $H I G H \_A Q$, that takes the value of one if $A Q$ for the 4-digit NAICS industry is above the yearly mean for the pooled sample and zero otherwise. Transforming $A Q$ in an indicator variable facilitates interpretation where the interaction term between $H I G H \_A Q$ and $C O M P$ captures the incremental effect of operating in an industry with accounting quality above the sample mean on the relation between accounting comparability and productivity. Table 6 presents the results for this analysis. Supporting hypothesis 5, the coefficient on the interaction variable $C O M P^{*} H I G H \_A Q$ is positive and significant (coeff: 0.012; t-stat: 1.86). In line with prior literature (Biddle and Hilary, 2006; Biddle et al., 2009), this result suggests that higher accounting quality reduces information asymmetry between firms, hence facilitating subject firm learning from peer firms.

$$
<<\text { Insert Table } 6 \text { here >> }
$$

\subsection{Further analysis and robustness tests}

Although the focus of this study is on firm productivity because operating decision making is at the firm level, the association between accounting comparability and productivity should also be apparent at the industry level. Specifically, I expect industries that exhibit greater accounting comparability to exhibit greater industry productivity. As shown in the accompanying Internet 
Supplement, I find a significant positive association between industry accounting comparability and industry productivity suggesting that my firm level results can be extended to the industry level.

To ensure that my results are not biased by my empirical choices, I subject my results to several robustness tests. First, I test whether my results are robust to a tighter fixed effects structure by including interactions between the 4-digit NAICS industry fixed effects and year fixed effects in Eq.1. Second, I test whether my results are robust to different measures of accounting comparability. Third, I test whether the observed relation between accounting comparability and subject firm productivity is driven by similarity of accounting policies or similarity in how accounting policies are implemented. Fourth, I test whether my results are robust to different measures of firm productivity. Fifth, I test whether my results are influenced by the subject firm stock of intangible assets. Sixth, I test whether conditional conservative accounting influences my results. Results for these robustness tests, presented in the accompanying Internet Supplement, provide support to the positive relation between accounting comparability and firm productivity.

\section{Conclusion}

The availability of detailed production activity data over the last decade has enabled researchers in fields such as macroeconomics and labor economics to study the causes and consequences of productivity. Notwithstanding this, there is a paucity of literature examining the relation between accounting and productivity. This study seeks to fill this void by examining the association between accounting comparability and firm productivity. I posit that accounting comparability facilitates learning from peer firms, hence improving subject firm productivity. While prior studies such as Chen et al. (2018) and Chircop et al. (2020) show that accounting comparability improves investment decision making, it is not obvious that the benefits of accounting comparability extend to operational decision making. While investment decision 
making relates to one-off events, in this study I examine the relation between accounting comparability and day-to-day decision making.

Findings suggest a positive relation between accounting comparability and firm productivity. A channel through which accounting comparability is related to firm productivity is improved inventory management. I find that accounting comparability is related to lean inventory management practices, and that in turn, such practices are related to increased firm productivity. In cross-sectional analysis, I find that the relation between accounting comparability and firm productivity is stronger when, 1) peer firms exhibit high productivity and provide more informative filings; 2) subject firms exhibit high product similarity with peer firms and face stiffer competition, and 3) subject firms operate in industries characterized by higher accounting quality. 


\section{References}

Ackerberg, D.A., , C.L. Benkard, S. Berry, and A. Pakes. 2007. Econometric tools for analyzing market outcomes in Handbook for Econometrics Vol. 6A (eds) Heckman, J. and E. Learner, North Holland.

Ackerberg, D.A., K. Caves, and G. Frazer. 2015. Identification properties of recent production function estimators. Econometrica 83: 2411-2451.

Aigner, D., C.A.K. Lovell, and P. Schmidt. 1977. Formulation and estimation of stochastic frontier production function models. Journal of Econometrics, 6, 21-37.

Arnold, J., G. Nicoletti, and S. Scarpetta. 2008. Regulation, allocative efficiency and productivity in OECD countries: Industry and firm-level evidence. Organization for Economic Co-operation and Development Economics Department Working Paper 616.

Atalay, E., A. Hortaḉsu, and C. Syverson. 2012. Why do firms own production chains? National Bureau of Economic Research (NBER) Working Paper 18020.

Badertscher, B., N. Shroff, and H.D. White. 2013. Externalities of public firm presence: Evidence from private firms' investment decisions. Journal of Financial Economics 109, 682-706.

Banker, R.D. and R.C. Morey. 1986. Efficiency analysis for exogenously fixed inputs and outputs. Operations Research, 34, 513-521.

Barrios, J., P. Lisowsky, and M. Michael. 2019. Measurement matters: Financial reporting and productivity.University of Chicago and Boston University Working Paper.

Bartelsman, E.J., J.E. Haskel, and R. Martin. 2008. Distance to which frontier? Evidence on productivity convergence from international firm-level data. Centre for Economic Policy Research Discussion Paper 7032.

Basu, S., 1997. The conservatism principle and the asymmetric timeliness of earnings. Journal of Accounting and Economics 24, 3-37.

Beatty, A., S. Liao, and J.J. Yu. 2013. The spillover effect of fraudulent financial reporting on peer firms' investments. Journal of Accounting and Economics 55, 183-205.

Biddle, G.C., and G. Hilary. 2006. Accounting quality and firm-level capital investment. The Accounting Review 81, 963-982.

Biddle, G.C., G. Hilary, and R. S. Verdi. 2009. How does financial reporting quality relate to investment efficiency? Journal of Accounting and Economics 48, 112-131.

Bloom, N., and J. Van Reenen. 2007. Measuring and Explaining Management Practices Across Firms and Countries. The Quarterly Journal of Economics 122, 1351-1408.

Bloom, N., M. Darca, and J. Van Reenen. 2011. Trade induced technical change? The impact of chinese imports on innovation, IT and productivity. National Bureau of Economic Research (NBER) Working Paper 16717.

Bloom, N., M. Schankerman, and J. Van Reenen. 2013. Identifying technology spillovers and product market rivalry. Econometrica 81, 1347-1393.

Breunig, R., and M.H. Wong. 2005. Estimation of total factor productivity in Quantitative Tools for Microeconomic Policy Analysis, Productivity Commission Conference Proceedings, 17-18 November 2004, Canberra.

Bridgman, B., S. Qi, and J.A. Schmitz. 2009. The economic performance of cartels: Evidence from the New Deal US Sugar Manufacturing Carterl, 1934-74. Federal Reserve Bank of Minneapolis Staff Report 437.

Charnes, A., W.W. Cooper, and E. Rhodes. 1978. Mesuring efficiency of decision making units. European Journal of Operational Research, 2, 492-444.

Chen, H., M.Z. Frank, and O.Q. Wu. 2005. What actually happened to the inventories of American Companies between 1981 and 2000? Management Science 51, 1015-1031.

Chen, C.W., D.W. Collins, T.D. Kravet, and R. Mergenthaler. 2018. Financial Statement Comparability and the Efficiency of Acquisition Decisions. Contemporary Accounting Research 35, 164-202.

Chircop, J., D.W. Collins, L.H. Hass, and N.Q. Nguyen. 2020 Accounting comparability and corporate innovative efficiency. The Accounting Review 95, 127-151.

Choi, J.H. 2021. Accrual accounting and resource allocation: A general equilibrium analysis. Journal of Accounting Research 59, 1179-1219. 
Collard-Wexler, A. 2013. Demand fluctuations in the Ready-Mix Concrete Industry. Econometrica 81, 1003-1037.

Collins, D.W., S.P. Kothari, J. Shanken, and R.G. Sloan. 1994. Lack of timeliness and noise as explanations for the low contemporaneous return-earnings association. Journal of Accounting and Economics 18, 289-324.

Crespi, G., C. Criscuolo, J.E. Haskel, and M. Slaughter. 2008. Productivity growth, knowledge flows and spillovers. National Bureau of Economic Research (NBER) Working Paper 13959.

Darrough, M., H. Kim, and E. Zur. 2018. The impact of corporate welfare policy on firm-level productivity: Evidence from unemployment insurance. Journal of Business Ethics 159, 795815.

David, J.M., A.H. Hopenhayn, and V. Venkateswaran. 2016. Information, misallocation and aggregate productivity. The Quarterly Journal of Economics, 943-1005.

De Franco, G., S.P. Kothari, and R.S. Verdi. 2011. The Benefits of Financial Statement Comparability. Journal of Accounting Research 49, 895-931.

Dechow, M.P., and I.D. Dichev. 2002. The Quality of Accruals and Earnings: The Role of Accural Estimation Errors. The Accounting Review 77, 35-59.

Dichev, I. D., J.R. Graham, C.R. Harvey, and S. Rajgopal. 2013. Earnings quality: Evidence from the field. Jouranl of Accounting and Economics 56, 1-33.

Doraszelski, U., and J. Jaumandreu. 2013. R\&D and productivity: Estimating endogenous productivity. Review of Economic Studies 80, 1338-1383.

Fabrizio, K.R., N.L. Rose, and C.D. Wolfram. 2007. Do markets reduce costs? Assessing the impact of regulatory restructuring on US electric generation efficiency. American Economic Review 97, 1250-1277.

FASB. 2010. Statement of Financial Accounting Concepts No. 8: Conceptual Framework for Financial Reporting.

Feng, M., L. Chan, and S. McVay. 2009. Internal control and management guidance. Journal of Accounting and Economics 48, 190-209.

Greenston, M., J. A. List, and C. Syverson. 2012. The effects of environmental regulation on the competitiveness of US manufacturing? National Bureau of Economic Research (NBER) Working Paper 18392.

Griffith, R., R. Harrison, and J. Van Reenen. 2006. How special is the special relationship? Using the impact of US R\&D spillovers on UK firms as a test of technology sourcing. American Economic Review 96, 1859-1875.

Goodman, T.H., Neamtiu, M., Shroff, N., and H.D. White. 2014. Management forecast quality and capital investment decisions. The Accounting Review 89, 331-365.

Hann, N.R., H. Kim, W. Wang, and Y. Zheng. 2020. Information Frictions and Productivity Dispersion: The Role of Accounting Information. The Accounting Review 95: 223-250.

Hasan, I., N. Kobeissi, L. Liu, and H. Wang. 2018. Corporate social responsibility and firm financial performance: The mediating role of productivity. Journal of Business Ethics 149, 671-688.

Hoberg, G., and G. Phillips. 2016. Text-based network industries and endogenous product differentiation. Journal of Political Economy 124, 1423-1465.

Hortaḉsu, A., and C. Syverson. 2007. Cementing relationships: Vertical integration, foreclosure, productivity and prices. Journal of Political Economy 115, 250-301.

Hsieh, C.T., and P.J. Klenow. 2009. Misallocation and manufacturing TFP in China nad India. The Quarterly Journal of Economics 124, 1329-1372.

Imrohoroglu, A., and S. Tuzel. 2014. Firm-level productivity, risk and return. Management Science 60, 2073-2090.

Jones, J.J. 1991. Earnings management during import relief investigation. Journal of Accounting Research 29, 193-228.

Keller, W., and S.R. Yeaple. 2009. Multinational enterprises, international trade and productivity growth: Firm level evidence from the United States. Review of Economics and Statistics 91, 821-831. 
Kellog, R. 2009. Learning by drilling:Inter-frim learning and relationship persistences in the Texas oilpatch. National Bureau of Economic Research (NBER) Working Paper 15060.

Knittel, C.R. 2002. Alternative regulatory methods and firm efficiency: Stochastic frontier evidence from the US Electricity industry. Review of Economics and Statistics 84, 530-540.

Lev, B., and T. Sougiannis. 1996. The capitalization, amortization, and value-relevance of R\&D. Journal of Accounting and Economics 21, 107-138

Levinsohn, J., and A. Petrin. 2003. Estimating production functions using inputs to control for unobservables. The Review of Economic Studies 70, 317-341.

Livdan, D., H. Sapriza, and L. Zhang. 2009. Financially constrained stock returns. The Journal of Finance 64, 1827-1862.

Loughran, T., and B. Mcdonald. 2014. Measuring readability in financial disclosures. The Jouranl of Finance 69, 1643-1671.

Maksimovic, V., and G. Phililips. 2002. Do conglomerate firms allocate resources inefficiently across industries? Theory and evidence. Journal of Finance 57, 721-767.

McNichols, M. 2002. The quality of accruals and earnings: The role of accrual estimation errors: Discussion. The Accounting Review 77, 61-69.

Meeusen, W. and J. van den Broeck. 1977. Efficiency estimation from Cobb-Douglas production functions with composed errors. International Economic Review, 18, 435-444.

Olley, G.S., and A. Pakes. 1996. The dynamics of productivity in the Telecommications Equipment Industry. Econometrica 64, 245-276.

Pavcnik, N. 2002. Trade liberalization, exit and productivity improvement: Evidence from Chilean plants. Review of Economic Studies 69, 245-276.

Peterson, K., R. Schmardebeck, and T.J. Wilks. 2015. The earnings quality and information processing effects of accounting consistency. The Accounting Review 90, 2483-2514.

Restuccia, D., and R. Rogerson. 2008. Policy distortions and aggregate productivity with heterogeneous establishments. Review of Economic Dynamics 11, 707-720.

Schmitz, J.A. 2005. What determines productivity? Lessons from the dramatic recovery of the US and Canadian Iron Ore industries following their early 1980s crisis. Journal of Political Economy $113,582-625$.

Schoar, A. 2002. Effects of corporate diversification on productivity. Journal of Finance 57, 23792403.

Serpa, J.C., and H. Krishnan. 2017. The impact of supply chains on firm-level productivity. Management Science 62, 511-532.

Shroff, N., R. Verdi, and Y. Gwen. 2014. Information environment and the investment decisions of multinational corporations. The Accounting Review 89, 759-790.

Shroff, N. 2017. Corporate investment and changes in GAAP. Review of Accounting Studies 22, 1-57.

Syverson, C. 2004a. Product substitutability and productivity dispersion. Review of Economics and Statistics 86, 534-550.

Syverson, C. 2004b. Market structure and productivity: A concrete example. Journal of Political Economy 112, 1181-1222.

Syverson, C. 2011. What determines productivity? Journal of Economic Literature 49, 326-365.

To, Y.T., M. Navone, and E. Wu. 2018. Analyst coverage and the quality of corporate investment decisions. Journal of Corporate Finance 51, 164-181.

Wooldridge, J. 2009. On Estimating Firm-Level Production Functions Using Proxy Variables to Control for Unobservables. Economics Letters 104, 112-114.

Yasar, M., R. Raciborski, and B. Poi. 2008. Production function estimation in Stata using the Olley and Pakes Method. The Stata Journal 8, 221-231. 
FIGURE 1

TIMELINE FOR THE RELATION BETWEEN ACCOUNTING COMPARABILITY AND FIRM PRODUCTIVITY

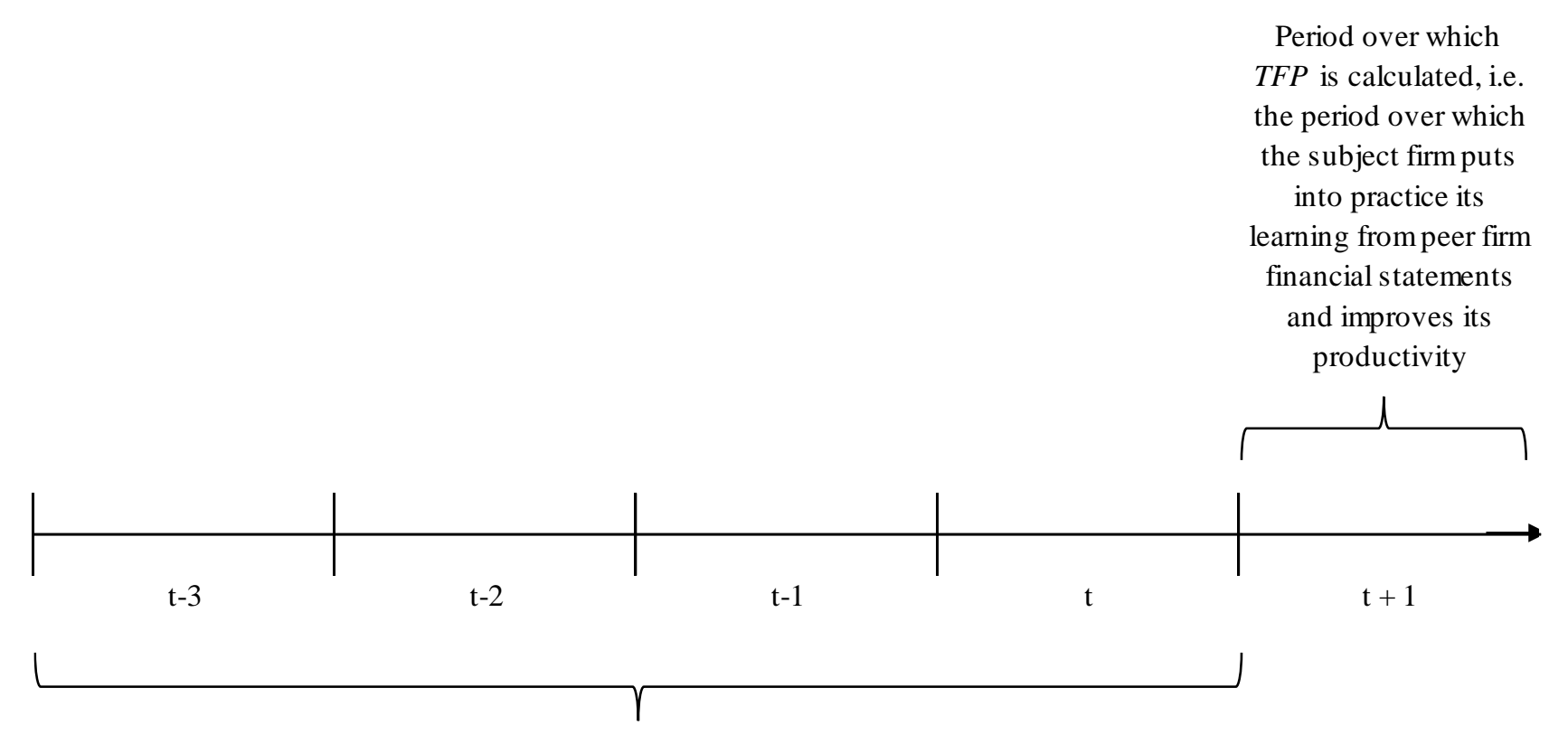

Period over which COMP is calculated, i.e., the period over which the subject firm observes and learns from the peer firm financial statements

Figure 1: A timeline of the relation between accounting comparability and firm productivity. 
TABLE 1

SUMMARY STATISTICS

Panel A: Variable distribution statistics

\begin{tabular}{lrrrrr} 
Variable & P25 & Mean & Median & P75 & Std. Dev. \\
\hline & & & & & \\
TFP & -0.195 & -0.019 & -0.038 & 0.163 & 0.420 \\
COMP & -3.700 & -3.037 & -2.630 & -1.871 & 1.882 \\
SIZE & 4.207 & 5.868 & 5.727 & 7.373 & 2.164 \\
AGE & 2.303 & 2.839 & 2.833 & 3.367 & 0.719 \\
MTB & 1.320 & 2.909 & 2.093 & 3.360 & 2.829 \\
LEV & 0.001 & 0.431 & 0.170 & 0.519 & 0.839 \\
CAPINT & 4.862 & 5.461 & 5.387 & 5.992 & 0.869 \\
TOBINQ & 0.894 & 1.743 & 1.300 & 2.041 & 1.386 \\
CURRENTRATIO & 1.736 & 3.225 & 2.453 & 3.859 & 2.372 \\
IO & 0.000 & 0.333 & 0.248 & 0.638 & 0.330 \\
SEG & 1.792 & 2.423 & 2.565 & 3.045 & 0.735 \\
AQ & 0.333 & 0.599 & 0.667 & 0.778 & 0.268 \\
SYNC & 0.026 & 0.140 & 0.082 & 0.217 & 0.147 \\
CORR & 0.111 & 0.191 & 0.177 & 0.261 & 0.114 \\
STDOCF & 0.333 & 0.568 & 0.556 & 0.778 & 0.313 \\
\hline
\end{tabular}




\begin{tabular}{|c|c|c|c|c|c|c|c|c|c|c|c|c|c|c|c|c|}
\hline No. & Variable & 1 & 2 & 3 & 4 & 5 & 6 & 7 & 8 & 9 & 10 & 11 & 12 & 13 & 14 & 15 \\
\hline 1 & TFP & 1.000 & & & & & & & & & & & & & & \\
\hline 2 & COMP & 0.080 & 1.000 & & & & & & & & & & & & & \\
\hline 3 & SIZE & 0.025 & 0.077 & 1.000 & & & & & & & & & & & & \\
\hline 4 & AGE & -0.051 & 0.140 & 0.405 & 1.000 & & & & & & & & & & & \\
\hline 5 & МТВ & 0.167 & 0.003 & 0.104 & -0.011 & 1.000 & & & & & & & & & & \\
\hline 6 & LEV & -0.029 & -0.015 & 0.213 & 0.049 & 0.252 & 1.000 & & & & & & & & & \\
\hline 7 & CAPINT & 0.239 & -0.108 & 0.455 & 0.048 & 0.131 & 0.015 & 1.000 & & & & & & & & \\
\hline 8 & TOBINQ & 0.246 & 0.006 & -0.014 & -0.119 & 0.800 & -0.119 & 0.182 & 1.000 & & & & & & & \\
\hline 9 & CURRENTRATIO & 0.088 & -0.003 & -0.288 & -0.188 & -0.013 & -0.217 & 0.192 & 0.225 & 1.000 & & & & & & \\
\hline 10 & IO & 0.046 & 0.158 & 0.351 & 0.214 & $\mathbf{0 . 0 5 3}$ & 0.025 & 0.112 & 0.047 & -0.035 & 1.000 & & & & & \\
\hline 11 & SEG & -0.090 & -0.086 & 0.486 & 0.254 & -0.001 & 0.045 & 0.325 & -0.051 & -0.113 & 0.197 & 1.000 & & & & \\
\hline 12 & AQ & -0.026 & -0.204 & 0.341 & 0.190 & 0.054 & 0.046 & 0.477 & 0.007 & -0.016 & 0.040 & 0.463 & 1.000 & & & \\
\hline 13 & SYNC & -0.025 & -0.015 & 0.576 & 0.239 & $\mathbf{0 . 0 3 3}$ & 0.024 & 0.408 & 0.017 & -0.010 & 0.264 & 0.547 & 0.393 & 1.000 & & \\
\hline 14 & CORR & -0.088 & -0.063 & 0.392 & 0.097 & -0.042 & 0.017 & 0.284 & -0.047 & -0.001 & 0.210 & 0.408 & 0.271 & 0.631 & 1.000 & \\
\hline 15 & STDOCF & 0.081 & 0.122 & 0.027 & 0.054 & -0.143 & 0.020 & -0.055 & -0.146 & -0.009 & $\mathbf{0 . 0 3 3}$ & 0.013 & -0.046 & 0.003 & 0.011 & 1.000 \\
\hline
\end{tabular}

Table 1: Panel A shows variable distribution statistics and Panel B shows the Pearson correlation matrix, for the variables used in baseline model, Eq.7. Correlation coefficients in bold denote significance at the 10\% level. TFP, total factor productivity, is calculated using the approach proposed by Olley and Pakes (1996) with the Ackerberg et al. (2015) correction; COMP, accounting comparability is calculated as in De Franco et al. (2011); SIZE is the log of total assets; $A G E$ is the difference between year $t$ and the first year in which the firm first appears in CRSP; $M T B$, market-to-book ratio, is calculated as the firm market capitalization at financial year end scaled by net assets; $L E V$, leverage, is computed as long-term debt scaled by total shareholders' equity; CAPINT capital intensity, is calculated as the log of total assets scaled by the number of employees; TOBINQ is the sum of firm market value and total debt scaled by total assets; CURRENTRATIO, current ratio, is calculated as current assets scaled by current liabilities, IO institutional ownership, is calculated as the number of shares held by institutional owners scaled by the number of outstanding shares at financial year end, $S E G$ Number of segments, calculated as the log of the number of firm segments at financial year end; $A Q$ accounting quality, is calculated as the standard deviation of residuals from an OLS regression where change in working capital is a function of lag operating cash flows, operating cash flows, lead operating cash flows, change in sales and property plant and equipment. The regression is run by 4-digit NAICS industry. SYNC synchronicity, is calculated as the adjusted r-squared from a market model OLS regression run over the same 16 quarters used to compute COMP. CORR correlation, is calculated as the average correlation of a subject firm return with peer firm returns. Correlation is calculated for all subject firmpeer firm combination within the same 4-digit NAICS industry over the same 16-quarters used to calculate COMP. STDOCF, operating cash flow volatility, is calculated as the coefficient of variation of operating cash flows for the same 16-quarters used to calculate COMP. 
TABLE 2

\section{ACCOUNTING COMPARABILITY AND FIRM PRODUCTIVITY}

\begin{tabular}{|c|c|c|c|}
\hline \multirow[t]{2}{*}{ Variable } & \multicolumn{3}{|c|}{$\mathrm{TFP}_{(\mathrm{t}+1)}$} \\
\hline & Coeff. & Sig. & $\mathrm{t}$-Stat. \\
\hline COMP & 0.020 & $* * *$ & 6.19 \\
\hline SIZE & -0.010 & & -1.50 \\
\hline AGE & -0.004 & & -0.45 \\
\hline MTB & -0.011 & $* * *$ & -3.49 \\
\hline LEV & 0.010 & & 1.35 \\
\hline CAPINT & 0.168 & $* * *$ & 12.42 \\
\hline TOBINQ & 0.082 & $* * *$ & 8.20 \\
\hline CURRENTRATIO & -0.010 & $* *$ & -2.57 \\
\hline IO & 0.051 & $* *$ & 2.26 \\
\hline SEG & -0.039 & $* *$ & -2.25 \\
\hline AQ & -0.123 & $* * *$ & -3.27 \\
\hline SYNC & -0.043 & & -0.45 \\
\hline CORR & -0.382 & $* * *$ & -4.63 \\
\hline STDOCF & 0.152 & $* * *$ & 7.52 \\
\hline Constant & -0.550 & $* * *$ & -6.54 \\
\hline Industry F.E. & & Yes & \\
\hline Year F.E. & & Yes & \\
\hline S.E. clustered by firm and year & & Yes & \\
\hline Observations & & 16,340 & \\
\hline R-squared & & 0.177 & \\
\hline Adjusted R-squared & & 0.175 & \\
\hline
\end{tabular}

Table 2: The table shows the results for Eq.7 testing for the association between accounting comparability and firm productivity. All variables are defined in Table $1 . * * *$ and $* * *$ denote significance at the $10 \%, 5 \%$ and $1 \%$ level of significance respectively. 
TABLE 3

\section{ACCOUNTING COMPARABILITY, LEAN INVENTORY MANAGEMENT AND FIRM PRODUCTIVITY}

Panel A: Accounting comparability and lean inventory management

(1)

\begin{tabular}{|c|c|c|c|c|c|c|}
\hline \multirow[t]{2}{*}{ Variable } & \multicolumn{3}{|c|}{ AB_WIP $(t+1)$} & \multicolumn{3}{|c|}{ AB_WIP $(t+1)$} \\
\hline & Coeff. & Sig. & t-Stat. & Coeff. & Sig. & $\mathrm{t}-$ Stat. \\
\hline COMP*LOW_PEERWIP & & & & -0.055 & $*$ & -1.74 \\
\hline LOW_PEERWIP & & & & -0.235 & $*$ & -1.66 \\
\hline COMP & -0.031 & $* * *$ & -3.10 & 0.031 & & 0.94 \\
\hline SIZE & -0.023 & & -1.49 & -0.025 & & -1.61 \\
\hline AGE & 0.092 & $* *$ & 2.52 & 0.092 & $* *$ & 2.52 \\
\hline МТВ & 0.019 & $*$ & 1.69 & 0.019 & $*$ & 1.71 \\
\hline LEV & -0.056 & $* * *$ & -2.79 & -0.055 & $* * *$ & -2.74 \\
\hline CAPINT & -0.206 & $* * *$ & -6.78 & -0.205 & $* * *$ & -6.79 \\
\hline TOBINQ & -0.062 & $* * *$ & -2.62 & -0.063 & $* * *$ & -2.71 \\
\hline CURRENTRATIO & 0.022 & & 1.53 & 0.021 & & 1.50 \\
\hline IO & 0.050 & & 0.89 & 0.052 & & 0.95 \\
\hline SEG & -0.010 & & -0.23 & -0.011 & & -0.25 \\
\hline $\mathrm{AQ}$ & 0.082 & & 0.71 & 0.087 & & 0.76 \\
\hline SYNC & -0.393 & $* *$ & -2.02 & -0.403 & $* *$ & -2.07 \\
\hline CORR & -0.082 & & -0.44 & -0.068 & & -0.36 \\
\hline STDOCF & 0.061 & & 1.34 & 0.059 & & 1.31 \\
\hline Constant & 0.670 & $* * *$ & 3.42 & 0.933 & $* * *$ & 3.80 \\
\hline Industry F.E. & & Yes & & & Yes & \\
\hline Year F.E. & & Yes & & & Yes & \\
\hline $\begin{array}{l}\text { S.E. clustered by firm and } \\
\text { year }\end{array}$ & & Yes & & & Yes & \\
\hline Observations & & 13,983 & & & 13,983 & \\
\hline R-squared & & 0.074 & & & 0.075 & \\
\hline Adjusted R-squared & & 0.071 & & & 0.072 & \\
\hline
\end{tabular}


Panel B: Lean inventory management and firm productivity

\begin{tabular}{|c|c|c|c|}
\hline \multirow[t]{2}{*}{ Variable } & \multicolumn{3}{|c|}{$\operatorname{TFP}_{(t+1)}$} \\
\hline & Coeff. & Sig. & t-Stat. \\
\hline $\mathrm{AB}_{-} \mathrm{WIP}_{(\mathrm{t}+1)}$ & -0.013 & $*$ & -1.82 \\
\hline COMP & 0.020 & $* * *$ & 5.70 \\
\hline SIZE & -0.007 & & -1.04 \\
\hline AGE & -0.003 & & -0.33 \\
\hline МТB & -0.016 & $* * *$ & -4.32 \\
\hline LEV & 0.018 & $* *$ & 2.25 \\
\hline CAPINT & 0.155 & $* * *$ & 10.17 \\
\hline TOBINQ & 0.086 & $* * *$ & 7.87 \\
\hline CURRENTRATIO & -0.010 & $* * *$ & -2.61 \\
\hline IO & 0.060 & $* *$ & 2.47 \\
\hline SEG & -0.046 & $* * *$ & -2.74 \\
\hline AQ & -0.093 & $* *$ & -2.24 \\
\hline SYNC & 0.001 & & 0.01 \\
\hline CORR & -0.441 & $* * *$ & -5.17 \\
\hline STDOCF & 0.157 & $* * *$ & 7.75 \\
\hline Constant & -0.483 & $* * *$ & -5.09 \\
\hline Industry F.E. & & Yes & \\
\hline Year F.E. & & Yes & \\
\hline S.E. clustered by firm and year & & Yes & \\
\hline Observations & & 13,983 & \\
\hline R-squared & & 0.172 & \\
\hline Adjusted R-squared & & 0.170 & \\
\hline
\end{tabular}

Table 3: The table shows the results for an analysis examining the relation between accounting comparability, lean inventory management and firm productivity. Panel A shows the results for an analysis examining the relation between accounting comparability and work-in-process inventory and Panel B shows the results for an analysis examining the relation between accounting comparability, work-in-process inventory and firm productivity. $A B_{-} W I P$ is the industry standardized holdings of work-in-process inventory scaled by total assets. $L O W \_P E E R W I P$ is an indicator variable that takes the value if one if at least one of the four peer firms with the highest accounting comparability with the subject firm has a negative $A B \_W I P$. COMP*LOW_PEERWIP denotes an interaction between COMP and LOW_PEERWIP. All other variables are defined in Table $1 . * * *$ and $* * *$ denote significance at the $10 \%, 5 \%$ and $1 \%$ level of significance respectively. 
TABLE 4

\section{ACCOUNTING COMPARABILITY, FIRM PRODUCTIVITY AND PEER FIRM CHARACTERISTICS}

Panel A: Accounting comparability and peer firm productivity

\begin{tabular}{|c|c|c|c|}
\hline \multirow[t]{2}{*}{ Variable } & \multicolumn{3}{|c|}{$\operatorname{TFP}_{(t+1)}$} \\
\hline & Coeff. & Sig. & $\mathrm{t}-$ Stat. \\
\hline COMP*HIGH_PEERTFP & 0.013 & $*$ & 1.82 \\
\hline HIGH_PEERTFP & 0.162 & $* * *$ & 6.27 \\
\hline COMP & 0.009 & $* * *$ & 2.81 \\
\hline SIZE & -0.015 & $* *$ & -2.26 \\
\hline AGE & -0.006 & & -0.63 \\
\hline MTB & -0.010 & $* * *$ & -2.98 \\
\hline LEV & 0.009 & & 1.27 \\
\hline CAPINT & 0.169 & $* * *$ & 12.60 \\
\hline TOBINQ & 0.084 & $* * *$ & 8.45 \\
\hline CURRENTRATIO & -0.011 & $* * *$ & -2.80 \\
\hline IO & 0.050 & $* *$ & 2.23 \\
\hline SEG & -0.043 & $* *$ & -2.55 \\
\hline AQ & -0.121 & $* * *$ & -3.24 \\
\hline SYNC & -0.031 & & -0.34 \\
\hline CORR & -0.361 & $* * *$ & -4.48 \\
\hline STDOCF & 0.132 & $* * *$ & 6.75 \\
\hline Constant & -0.654 & $* * *$ & -7.45 \\
\hline Industry F.E. & & Yes & \\
\hline Year F.E. & & Yes & \\
\hline S.E. clustered by firm and year & & Yes & \\
\hline Observations & & 16,216 & \\
\hline R-squared & & 0.192 & \\
\hline Adjusted R-squared & & 0.190 & \\
\hline
\end{tabular}


Panel B: Accounting comparability and the size and length of peer firm filings

(1)

Variable

$\operatorname{TFP}_{(t+1)}$
(2)

$\operatorname{TFP}_{(t+1)}$

\begin{tabular}{|c|c|c|c|c|c|c|}
\hline & Coeff. & Sig. & t-Stat. & Coeff. & Sig. & t-Stat. \\
\hline COMP*HIGH_PEERFILESIZE & 0.010 & $*$ & 1.93 & & & \\
\hline HIGH_PEERFILESIZE & 0.030 & & 1.45 & & & \\
\hline COMP*HIGH_PEERWORDCOUNT & & & & 0.021 & $* * *$ & 4.03 \\
\hline HIGH_PEERWORDCOUNT & & & & 0.025 & & 1.59 \\
\hline COMP & 0.012 & $* *$ & 2.05 & 0.005 & & 1.04 \\
\hline SIZE & -0.009 & & -1.15 & -0.009 & & -1.27 \\
\hline AGE & -0.002 & & -0.19 & -0.002 & & -0.21 \\
\hline MTB & -0.011 & $* * *$ & -3.34 & -0.011 & $* * *$ & -3.36 \\
\hline LEV & 0.007 & & 0.98 & 0.008 & & 1.08 \\
\hline CAPINT & 0.168 & $* * *$ & 11.83 & 0.169 & $* * *$ & 11.94 \\
\hline TOBINQ & 0.082 & $* * *$ & 7.60 & 0.082 & $* * *$ & 7.65 \\
\hline CURRENTRATIO & -0.010 & $* *$ & -2.50 & -0.010 & $* *$ & -2.53 \\
\hline IO & 0.050 & $* *$ & 2.16 & 0.052 & $* *$ & 2.24 \\
\hline SEG & -0.041 & $* *$ & -2.28 & -0.040 & $* *$ & -2.29 \\
\hline $\mathrm{AQ}$ & -0.115 & $* * *$ & -2.74 & -0.113 & $* * *$ & -2.71 \\
\hline SYNC & -0.073 & & -0.73 & -0.081 & & -0.81 \\
\hline CORR & -0.371 & $* * *$ & -4.10 & -0.361 & $* * *$ & -3.99 \\
\hline STDOCF & 0.155 & $* * *$ & 6.88 & 0.154 & $* * *$ & 6.86 \\
\hline Constant & -0.541 & $* * *$ & -5.90 & -0.539 & $* * *$ & -6.16 \\
\hline Industry F.E. & & Yes & & & Yes & \\
\hline Year F.E. & & Yes & & & Yes & \\
\hline S.E. clustered by firm and year & & Yes & & & Yes & \\
\hline Observations & & 14,371 & & & 14,362 & \\
\hline R-squared & & 0.178 & & & 0.18 & \\
\hline Adjusted R-squared & & 0.175 & & & 0.178 & \\
\hline
\end{tabular}

Table 4: The table shows the results for an analysis examining the relation between accounting comparability, firm productivity and peer firm characteristics. Panel A shows the results for an analysis examining the effect of peer firm productivity on the relation between accounting comparability and subject firm productivity and Panel $B$ shows the results for an analysis examining the effect of the size and length of peer firm filings on the relation between accounting comparability and subject firm productivity. HIGH_PEERTFP is an indicator variable that takes the value of one if at least one of the four peer firms with the highest accounting comparability with the subject firm has a firm productivity above sample mean for the year and zero otherwise. COMP*HIGH_PEERTFP denotes an interaction between COMP and HIGH_PEERTFP. HIGH_PEERFILESIZE is an indicator variable that takes the value of one if at least one of the four peer firms with the highest accounting comparability with the subject firm has mean 10-Q and 10-K file size for the same 16-quarters used to calculate COMP above sample mean for the year and zero otherwise. COMP*HIGH_PEERFILESIZE denotes an interaction between COMP and HIGH_PEERFILESIZE. HIGH_PEERWORDCOUNT is an indicator variable that takes the value of one if at least one of the four peer firms with the highest accounting comparability with the subject firm has mean 10-Q and 10$\mathrm{K}$ word count for the same 16-quarters used to calculate COMP above sample mean for the year and zero otherwise. COMP*HIGH_PEERWORDCOUNT denotes an interaction between COMP and HIGH_PEERWORDCOUNT. All other variables are defined in Table $1 . * * *$ and $* * *$ denote significance at the $10 \%, 5 \%$ and $1 \%$ level of significance respectively. 
TABLE 5

\section{ACCOUNTING COMPARABILITY, FIRM PRODUCTIVITY AND SUBJECT FIRM CHARACTERISTICS}

Panel A: Accounting comparability, firm productivity and firm product similarity

\begin{tabular}{|c|c|c|c|}
\hline \multirow[t]{2}{*}{ Variable } & \multicolumn{3}{|c|}{$\operatorname{TFP}_{(t+1)}$} \\
\hline & Coeff. & Sig. & t-Stat. \\
\hline COMP*HIGH_SIM & 0.028 & $* *$ & 2.13 \\
\hline HIGH_SIM & 0.019 & & 0.65 \\
\hline COMP & 0.020 & $* * *$ & 5.05 \\
\hline SIZE & -0.006 & & -0.81 \\
\hline AGE & -0.002 & & -0.15 \\
\hline МТВ & -0.011 & $* * *$ & -3.37 \\
\hline LEV & 0.011 & & 1.36 \\
\hline CAPINT & 0.170 & $* * *$ & 11.41 \\
\hline TOBINQ & 0.083 & $* * *$ & 7.42 \\
\hline CURRENTRATIO & -0.008 & $*$ & -1.91 \\
\hline IO & 0.057 & $* *$ & 2.35 \\
\hline SEG & -0.041 & $* *$ & -2.31 \\
\hline AQ & -0.099 & $* *$ & -2.31 \\
\hline SYNC & -0.077 & & -0.87 \\
\hline CORR & -0.369 & $* * *$ & -3.96 \\
\hline STDOCF & 0.164 & $* * *$ & 7.34 \\
\hline Constant & -0.621 & $* * *$ & -6.32 \\
\hline Industry F.E. & & Yes & \\
\hline Year F.E. & & Yes & \\
\hline S.E. clustered by firm and year & & Yes & \\
\hline Observations & & 13,026 & \\
\hline R-squared & & 0.178 & \\
\hline Adjusted R-squared & & 0.176 & \\
\hline
\end{tabular}


Panel B: Accounting comparability, firm productivity and firm competition

\begin{tabular}{|c|c|c|c|}
\hline \multirow[t]{2}{*}{ Variable } & \multicolumn{3}{|c|}{$\operatorname{TFP}_{(t+1)}$} \\
\hline & Coeff. & Sig. & t-Stat. \\
\hline COMP*HIGH_COMPETITION & 0.022 & $* *$ & 2.17 \\
\hline HIGH_COMPETITION & 0.027 & & 1.05 \\
\hline COMP & 0.019 & $* * *$ & 4.47 \\
\hline SIZE & -0.006 & & -0.82 \\
\hline AGE & 0.002 & & 0.19 \\
\hline МTB & -0.012 & $* * *$ & -3.41 \\
\hline LEV & 0.010 & & 1.27 \\
\hline CAPINT & 0.164 & $* * *$ & 10.98 \\
\hline TOBINQ & 0.083 & $* * *$ & 7.22 \\
\hline CURRENTRATIO & -0.008 & $*$ & -1.88 \\
\hline IO & 0.056 & $* *$ & 2.28 \\
\hline SEG & -0.039 & $* *$ & -2.17 \\
\hline AQ & -0.098 & $* *$ & -2.29 \\
\hline SYNC & -0.069 & & -0.76 \\
\hline CORR & -0.397 & $* * *$ & -4.14 \\
\hline STDOCF & 0.163 & $* * *$ & 7.34 \\
\hline Constant & -0.611 & $* * *$ & -6.11 \\
\hline Industry F.E. & & Yes & \\
\hline Year F.E. & & Yes & \\
\hline S.E. clustered by firm and year & & Yes & \\
\hline Observations & & 13,026 & \\
\hline R-squared & & 0.176 & \\
\hline Adjusted R-squared & & 0.173 & \\
\hline
\end{tabular}

Table 5: The table shows the results for an analysis examining the relation between accounting comparability, firm productivity and subject firm characteristics. Panel A shows the results for an analysis examining the effect of subject firm product similarity on the relation between accounting comparability and subject firm productivity and Panel B shows the results for an analysis examining the effect of subject firm competition on the relation between accounting comparability and subject firm productivity. HIGH_SIM is an indicator variable that takes the value of one if subject firm product similarity is above the mean for the 4-digit NAICS industry - year, and zero otherwise. COMP*HIGH_PEERTFP denotes an interaction between COMP and HIGH_PEERTFP. HIGH_COMPETITION is an indicator variable that takes the value of one if subject firm HHI is below the mean for the 4-digit NAICS industry - year, and zero otherwise. COMP*HIGH_COMPETITION denotes an interaction between COMP and HIGH_COMPETITION. All other variables are defined in Table 1. *** and *** denote significance at the $10 \%, 5 \%$ and $1 \%$ level of significance respectively. 
TABLE 6

\section{ACCOUNTING COMPARABILITY, FIRM PRODUCTIVITY AND INDUSTRY CHARACTERISTICS}

\begin{tabular}{|c|c|c|c|}
\hline \multirow[t]{2}{*}{ Variable } & \multicolumn{3}{|c|}{$\operatorname{TFP}_{(t+1)}$} \\
\hline & Coeff. & Sig. & t-Stat. \\
\hline COMP*HIGH_AQ & 0.012 & $*$ & 1.86 \\
\hline HIGH_AQ & 0.061 & $* * *$ & 2.59 \\
\hline COMP & 0.013 & $* * *$ & 3.00 \\
\hline SIZE & -0.011 & $*$ & -1.66 \\
\hline AGE & -0.005 & & -0.56 \\
\hline MTB & -0.012 & $* * *$ & -3.51 \\
\hline LEV & 0.010 & & 1.46 \\
\hline CAPINT & 0.165 & $* * *$ & 12.19 \\
\hline TOBINQ & 0.083 & $* * *$ & 8.22 \\
\hline CURRENTRATIO & -0.010 & $* * *$ & -2.59 \\
\hline IO & 0.055 & $* *$ & 2.42 \\
\hline SEG & -0.038 & $* *$ & -2.21 \\
\hline SYNC & -0.036 & & -0.38 \\
\hline CORR & -0.395 & $* * *$ & -4.80 \\
\hline STDOCF & 0.152 & $* * *$ & 7.67 \\
\hline Constant & -0.600 & $* * *$ & -6.76 \\
\hline Industry F.E. & & Yes & \\
\hline Year F.E. & & Yes & \\
\hline S.E. clustered by firm and year & & Yes & \\
\hline Observations & & 16,340 & \\
\hline R-squared & & 0.176 & \\
\hline Adjusted R-squared & & 0.174 & \\
\hline
\end{tabular}

Table 6: The table shows the results for an analysis examining the relation between accounting comparability, firm productivity and industry characteristics. $H I G H \_A Q$ is an indicator variable that takes the value of one if the industry in which the subject firm operates has accounting quality above the sample mean and zero otherwise. $C O M P * H I G H \_A Q$ is an interaction variable between $C O M P$ and indicator variable $H I G H \_A Q$. All other variables are defined in Table 1. $* * *$ and $* * *$ denote significance of two-tailed tests at the $10 \%, 5 \%$ and $1 \%$ level of significance respectively. 